\title{
COMMUNICATION PATTERNS BASED ON SOCIAL MEDIA AS A POLITICAL MARKETING STRATEGY IN INDONESIAN DEMOCRATIC PARTY OF STRUGGLE
}

\author{
Gatut Priyowidodo ${ }^{*}$, Yustisia D. Sari ${ }^{1}$, Inri Inggrit I. ${ }^{1}$ and Samuel Gunawan ${ }^{1}$ \\ ${ }^{1}$ Department of Communication, Petra Christian University, Indonesia
}

\begin{abstract}
This research focus on the pattern of social media-based communication as a determinant of political marketing strategy on the organization of political parties in Indonesia. Research subjects were netizens either as members or administrators of political parties. They were party members and administrators who intensely speak to developments and issues of local election or chatting intensively to actual topics of concern or trending topic using whatApps, line, telegram, facebook applications. This research method using interpretive / qualitative paradigm which was studied based on netnography study. This method sought to deeply understand the life of the virtual community from the perspective of the perpetrator. The object of the netnographic study was netizens (members and administrators of political parties) with their activities and lives in a virtual world. Data were collected through site observation / broadcast / message service, in depth interview. Data were analyzed using site analysis and thematic analysis based on field data and processed with the help of NVIVO as a qualitative analysis tool. The result of this research that the communication patterns of Indonesian Democratic Party of Struggle (PDI Perjuangan) were formatted in three types: vertical pattern (member-board), horizontal pattern (members and administrators) and diagonal pattern (member-board-member and board-member-board).
\end{abstract}

Keywords: communication pattern, social media, political marketing strategy, netnography

\section{Introduction}

In the year 2018-2019, in Indonesia there are 17 election of governor, 115 election of bupati and 39 election of mayor. In total there are 171 regional head elections. Especially in the province of East Java, in addition to the election of governors, there are also 18 election regents / mayors. The 18 areas include Probolinggo, Sampang, Bangkalan, Bojonegoro, Nganjuk, Pamekasan, Tulungagung, Pasuruan, Magetan, Madiun, Lumajang, Bondowoso, Jombang, Malang, Mojokerto, Kediri City, Madiun City, and Town of Probolinggo.

Because of the massive political activity in Indonesia, this two years is called the political year. Year 2018 marks the election of regional heads simultaneously. The year 2019 marks the election of legislative members at the regional level (DPRD) and the national legislative members (DPR) as well as direct presidential / vice presidential elections.

Since the main movers of political activity are political parties, the political party machine must be able to work optimally. The choice is one, the political party must be smart and think carefully and decide what political marketing strategy to choose in order for the candidates who are brought, win the five-year contestation. The rapidly changing dynamics of voting societies requires that political parties have to be super-creative in finding the right formula to market or "sell" their candidates to electorates.

The Conventional ways press out the information in one direction, is outdated. The current and future strategy of political marketing must maximize online -based interactive communication with optimization of social media usage. Millennials are rational voters who are familiar with smartphone usage. 
That is why there is no other choice, every organization including a political party must adapt to the present. The communication pattern always runs linear with the latest development of information technology progress. Miller (2011) called modern information technology and organization a complementary attribute. Even since long time ago communication theorists put the latest media developments (the new media) have a major influence within the organization (Culnan \& Markus, 1987). Mediated communication pattern was successfully shifted conventional communication patterns. However, according to Daft and Lengel (1984) in his theory media richness, is still unable to defeat face to face communication. According to the theory, face to face communication is the richest medium of communication in the hierarchy followed by video phones, video conferences, telephones, electronic mail, personal documents, memos and letters, formal documents such as bulletins and flyers.

That is why, although humans are now entering the 21 st century or called the digital age (digital age) marked by a series of increasingly sophisticated information technology developments, still face-to-face communication is not replaceable. The packaging of voice technology (audio) and text by telephone, telex, telegram, short message service $(s m s)$ and email are not enough. People still want the visual appearance of the other person. This visual interactive communication is considered to be another form of face to face communication in this digital age. Long distances still allow anyone to interact as if they were facing each other.

That is the essential message that is captured, that no matter how great the improvement and the advancement of information technology, the nature of communication remains the same. Modified communication patterns, do not eliminate the essence. Morreale, Spitzberg and Barge (2006) called that communication as the transfer of messages or information, dividing the meaning of messages, persuasion and creating communication interaction persist.

The point of communication interaction only recognizes three levels, which are between individuals, individuals with groups or organizations and between organizations. This level of variety indicates that in all domains, individuals are important actors in producing and distributing messages. Then the particular message going back and forth within the organization must be well managed. Wrong message management easily creates message distortions that can lead to uncomfortable situations within the organization. Especially if focused on virtual organizations and not conventional.

In web-based organizations according to Daft \& Lewin (1993), employment relationships between employees and supervisors or management are modified in a new way. Which in turn produces and shapes the organizational culture that is the result of the interaction of communication patterns between netizens or service users and administrators as well. Knowingly or not, Indonesia is also undergoing a process of communication transformation patterns of conventional modern headed by maximizing the utilization of social media as a means of effective communication. The website of a political party other than as a virtual representation of the organization, is also used as a means of communication with members of the organization through its chatting page.

Website and social media other than as a means of interactive communication, can also be maximized as a means of political marketing strategy with the voter's audience without obstacles. Several previous studies related to the pattern of communication and organizational culture in virtual organizations with a netnography approach has not been done. Kozinet's (2002) study found that the netnography approach adopted from the ethnography method is particularly appropriate as an online marketing research technique to capture what consumer's desire. Another study conducted by Jiyao and Reynolds (2010) by using netnography that analyzed the collection of information and sales activities on online forums. Both are linked to the effectiveness of communication, persuasion 1 mode which is based on authority, emotion and logic. While Brodie, Illic, Juric and Hollebeek (2013) studies found that through a netnography approach can be traced to consumers in strengthening the knowledge of a brand can be incorporated in the virtual community about a brand or a particular brand. Similarly, conducted Mochazondida (2012) for example in particular research on tourism in 
cyberspace with netnography approach. His findings suggest that this new approach is a very relevant alternative approach to internet tourism research.

Research in Indonesia using a netnography perspective also only revolves around brands / brands and perceptions. As Listianingtyas (2013) studies show that the characteristics of the audience greatly affect the audience's perception of the Harley Davidson brand even though indirectly. Similarly Safitri research (2015) also focuses on personalized strategy of permeation. His findings suggest that the Marlo character maximizes instagram to build his personal brand through cross collaboration and side effects of buzzing multiple products before becoming a movie actor.

Rifai research (2016) found that the political marketing activities carried out Gerindra party in the 2014 legislative election in Kerawang District, it is still using conventional marketing tools. Similarly, the results of research conducted Utomo (2013) related to the use of social media in 'political marketing' Jokowi-Ahok in the 2012 elections DKI Jakarta, it gives a big influence in the victory of the couple. However, the study only focuses on literature review and does not touch how the interactions that occur between the user (user) as a selector with the selected.

Based on the phenomenon and tracing of previous research results above, it is clear that the research gap of this research lies in the chosen theme and approach taken. Netnography method has a very significant novelty element for the further development of organizational communication studies. As for the issue of research and research goal is to identify patterns of communication and marketing political strategy used by Indonesian Democratic Party of Struggle in maximizing the use of social media during Mayor Election (Election) 2018.

\section{Literature Review}

Virtual organization according to Mowshowitz (2002) is the most easily understandable concept as the management principle that maximally uses the application as a source of profit. Some early applications as a source of inspiration are virtual memory applications, virtual reality, virtual classrooms, virtual teams, and virtual offices. Virtual memory allows programmers to write code referring to storage that is not really available on the computer. Virtual reality allows the user to gain visual, auditory and sensational experience that is not in the normal human environment. The virtual class seems to present students studying in class as if it were true (Hiltz, 1994, in Mowshowitz, 2002). The virtual team allows managers to call groups of employees who have no formal relationship with each other (Hammer and Champy, 1993). Virtual office enables employees to operate in dynamic changing environments

The term "virtual organization" was introduced in the early 1980s and has since evolved with the development of information technology (Mowshowitz, 1994). According to Mowshowitz (2002), virtual organizations have at least five basic activities namely (1) analyzing the abstract needs; (2) determine the possibility of satisfying the needs; (3) tracking the allocation of satisfying needs; (4) maintain and enable revision of the procedure and (5) review and adjust the optimality of procedure allocation criteria. While the motive of the establishment of the virtual organization, according to Goldman, Nagel and Preiss (1995) is based on three things:

1. The Virtual Organization model reflects the competitor's need to create or combine production resources very quickly

2. The model of the virtual organization reflects the need for competitors to create or consolidate new productive resources frequently and concurrently, as the declining lifespan of individual products and services.

3. Virtual organizations reflect the complexity of today's highly profitable products, which often require access to world-level competition with a broader outlook such as research, prototyping, manufacturing, marketing, distribution, service and in each of these areas with more specialized competencies. 


\section{Communication Patterns}

The pattern of communication, simply can be explained as a form of representation of the relationship of complex elements in communicating, this form that explains the process of communication occurs. As a route, it has a plot that can be described and represents the reality of the communication process. The pattern of communication, at least helps humans to do interpretation of the meaning that is behind the communicative message. Communication patterns, made dynamically, because along the human communication that is not static. Following the needs and reality of human interaction itself, of course, follows the flow of the times.

In essence, communication pattern always describes the flow of messages from communicators to communicants who rely heavily on the media. Media becomes an important instrument for messages received intact and feedback occurs. Distortion of information and communication often occurs when messages are not fully accepted. This problem according to Mc Quail (2005) can be solved by optimizing the function of the media innovatively and creatively.

Pace and Faules (2010) mentions that there are five patterns of communication that occur within an organization in communication activities can be seen through the image below:

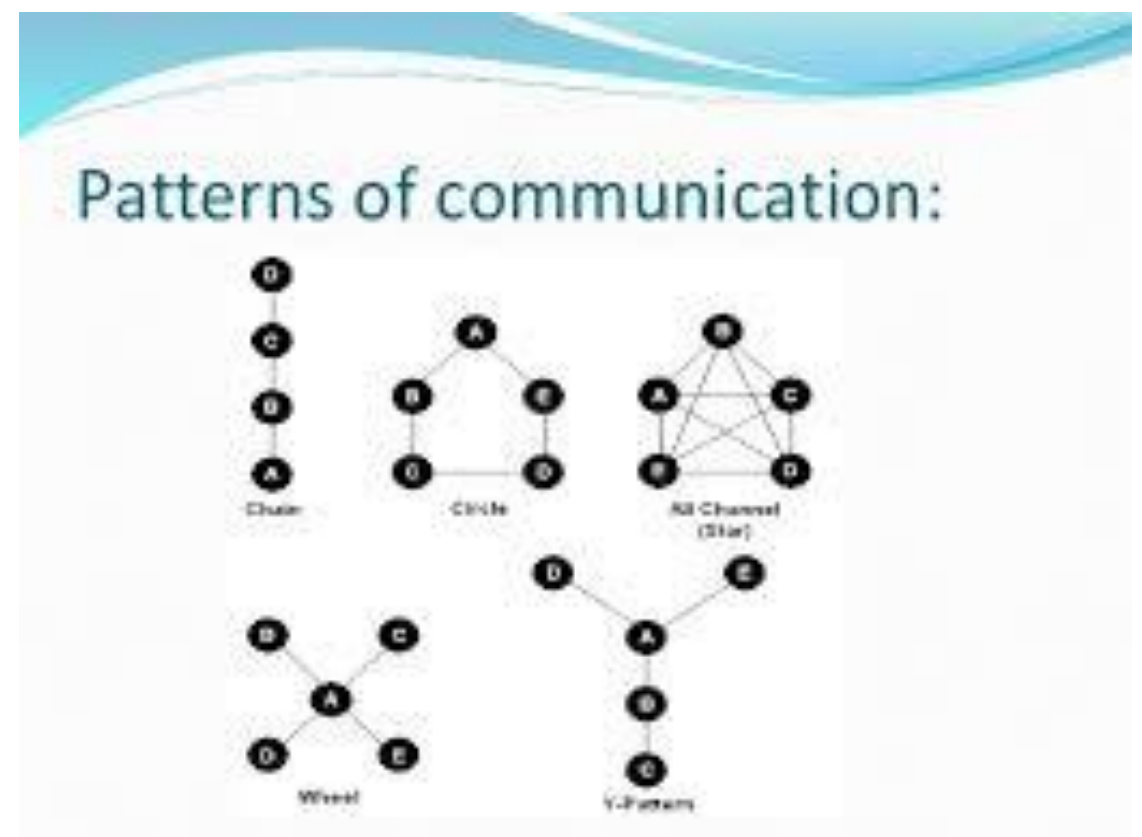

Figure 1. Organizational Communication Pattern

Source: Pace \& Faules, 2010

Meanwhile, Gibson and Hotgetts, (1991) and confirmed research results Priyowidodo (2013) said that the communication pattern can be formulated only into two, namely the formal communication pattern consists of upward and downward and informal communication patterns consist of cross channel, lateral and grapevine.

\section{Organizational Identification}

Identification is a means by which an organization member defines itself as having an association with the organization (Turner, 1987 in Wiesenfeld, et al. 1999). Thus, identification represents the binding social and psychological relationships between employees or members with the organization, a bond that continues to connect even if the member has been expelled. An organizational identity according to Dutton and Dukerich 
(1991) provides the answer to a question, what is the nature of the organization? According to him the identity of the organization has a role to guide, feelings, beliefs and behavior of members of the organization.

Identification becomes essential for the sustainability of virtual organizations, when the organization faces particular challenges following several factors. (1) Coordination and control of actors who can dissolve the organization, (2) working groups that can function, (3) strengthening the parties who can provide assistance and (4) have good quality employees. According to Dutton (1994) someone who has strong organizational identification can be traced from the following specific characteristics: (1) accepting organizational goals as personal goals, (2) following the boss's goals and (3) having loyalty and obedience. Organizational identification is expected to be closely related to hard work, extra strong will and performance. With employees having good organizational identification, companies can reduce the cost of producing goods and services because they do not require supervision and monitoring.

\section{Political Marketing Strategy}

Contemporary world of politics is changing, the relationship between constituents and political parties that are more pragmatic than ideological. The public will tend to vote on political parties based on programs offered by the party rather than just ideological ties. Constituents will vote with consideration of what solutions can be given by political parties or candidates on the issues that occur. This phenomenon is accompanied by an increase of non-partisan voters.

The situation supports political parties should have a specific strategy to attract the voice of its constituents. Thus, the relationship developed between constituents and political parties is more relational, no longer emotional as in the previous era. Vargo and Lusch (2004, in Firmanzah, 2008: 49) suggests that the exchange (exchange) between producers and consumers become the main model in social activities (marketing). The relationship between political parties and the society is very much in line with the concept of service companies, political parties offer solutions to the problems of society. In a marketing perspective, this relationship must be built continuously, sustainably. Not only with his supporters but with the wider community.

Lock and Harris (1996) emphasize that political marketing emphasizes communication with party members, the media and other important sources related to funding and election-related issues. The same is also presented by Wring (1997) who defines political marketing as the use of opinion and environmental analysis by parties or candidates to produce and offer competitive bids to realize organizational goals and satisfy voting groups.

O'Shaughnessy (2001, in Firmanzah, 2008, 156) asserts that political marketing is different from commercial marketing. Political marketing opens the concept of selling political parties or presidential candidates to voters but a concept that offers how a political party or contestant can make programs that deal with actual issues.

As described above in managing political marketing, political parties need a strategy to achieve their goals. Barber (2005: 212) describes the strategy as follows,

"The forming of the objective and the implementation of the tasks necessary to achieve these objectives with the pattern of consistency over time given the limitations of available resouces"

Formulate a political marketing strategy, its nature is not just short-term course in the election but also continuous and long-term nature. In formulating this political marketing strategy, political parties are also not just to win votes but more emphasis on how to build a reputation

Newman (1994) formulated a model of political marketing that has been applied to the Bill Clinton Era Election. Here is a model of market-oriented Newman / market: 


\section{Candidate Focus}

- Party Product

- Product Concept

- Selling Concept

- Marketing Concept

\section{The Marketing Campaign}

- Assess voter needs

- Profile voters

- Identify voter segment

\section{Environmental forces}

- Technology

- $\quad$ Structural shifts

- Power broker shifts in influence

\section{The Political Campaign}

- Preprimary stage

- Primary Stage

- Convention Stage

- General election stage

\section{Organizational culture}

Organizational culture according to Schein (1997) is a common basic assumption pattern learned by groups when solving external adaptation problems and internal integration that have functioned well enough to be considered legitimate and to be taught to new group members as the correct way to receive something, think and feel in relation to those problems. Meanwhile, according Harrey and Bown (1996 in Edwardin 2006) formulated as a system of shared values and beliefs that interacting with people, structures and systems of an organization to produce norms - norms and behavior. In general, organizational culture according to Chek (1996) can be defined as a set of norms of perception, behavior patterns created or developed in a company to overcome these basic assumptions or views that are believed to have been going well in the company so it is considered positive and appropriate to be taught to new employees as the right way to think and act in performing the task.

Robbins (1996) argues that organizational culture begins with the physiology of his thinking, once a culture of established practices within the organization acts to defend it, eg human resource management practices. Three forces play a vital part in maintaining a culture of selection, top management, and socialization methods. From the definition of organizational culture proposed by Schein (1997) can be seen that the formulation of a company's culture is based on the company's experience in solving the problems it faces which then usually become an ideal picture of how the company faces problems in the future. Because the problems faced by a company with other companies are different as well as different image or ideal view of a company with other companies, then the formulation of cultural inter-issue will be different too. Hofstede, Geert, Michael Harris Bond, and Chung-Leung (in Fuad Mas'ud, 2004) provide five dimensions that can be used as a framework in describing organizational culture. These five dimensions include: 1. Professionalism. 2. Distance from management. 3. Believing in colleagues 4. Regularity. 5. Integration. 


\section{Research Finding and Discussion}

Communication pattern in decision-making in the Indonesian Democratic Party of Struggle, the communication pattern is not divided into vertical, horizontal communication patterns and communication patterns diagonal. The formation of each communication pattern is not easy. Vertical communication patterns that emphasize the communication pattern of superiors (party elites) with subordinates (lower party members / administrators), are not easy to implement. This difficulty is seen when the Branch Board (DPC) Kediri will decide who will become the candidate for Head of Region / Mayor. This was acknowledged by the core board of the PDI Perjuangan Branch Board .He further explained:

"For the candidate itself, there is no communication. Do not consider DPC and DPD. Go directly to the DPP (Central Board). These symptoms occurred since the beginning. Actually at its inception, they have followed the selection, continue to follow the registration stages. But then there is a little problem at DPC level. Lastly with the DPD (Regional Board) also no communication. They should follow stages whose mechanism is regulated through DPC and DPD. But they go straight to the DPP. "

Although tinged by disharmonious relation between the candidates to be promoted to the board, but eventually DPP decided to partner -Azhar dr.Samsul Teguh Juniadi as a candidate of the Party of Struggle and his coalition, Hanura party. They will fight against the couple Abdullah Abu Bakar-Lilik Muhibbah (PAN, NASDEM, Democrat, and PKS) and Aizzudin-Sudjono Teguh (PKB, Golkar, PPP, and Gerindra). The three are competing for the seat of Mayor-Deputy Mayor of Kediri period 2018-2022in the 2018 regional head election simultaneously this year.

The non-existence of the nomination process implies DPC support to the candidates who are promoted also not too maximized. When the campaign period that took place from February 15, 2018 to June 23, 2018, the DPC is just waiting for the initiative of the candidate pair. DPC PDI Perjuangan is not too pro- active to propose candidates to constituents or voters. Explained by the Chairman of DPC PDI Perjuangan Kediri:

"Yes ... communication with candidates is limited to socialization, whereas now there is no socialization program so. The candidate will decide what he wants, and what program. It's up to him, what program and let us know as DPC to support ..."

If the DPC has not carried out any activities. Because we are tolerant of paslon (candidate pair), if the paslon has not moved, there may be other strategies that are prepared, so we support it.

Impressed that the couple who carried PDI Perjuangan is working alone with the volunteers. District or sub district administrators as party machines seem not working maximally. Recognized by Chairman of DPC PDI Struggle thus:

"It does not need to be so, because our work is also a lot. There are these programs, internal activities, and much more. Therefore we DPC, ahead of the election of Governor for example, also has the task, in order to help the candidate for governor of the current DPC gave us for socialization program in Kediri. All that we must also prepare. "

"No, when they do it themselves yes ... it's their responsibility, its success, treatment, etc."

"Because the one who has the winning desire is definitely the candidate pair"

The fact reinforces that there is a serious issue between candidate pairs carried by party officials at the DPC level. The reason for this is that the Branch Board considers that dr. Samsul Ashar-Teguh Juniadi is not the right couple. It was reinforced by the political realities in the field, that the PDI Perjuangan from the beginning 
proposed Abdullah Abu Bakar, the incumbent mayor (2013-2018) which has clearly controlled 15 thousand votes. Another defect, in which DPC PDI-P is reluctant to choose dr.Samsul Azhar because after not being mayor, he served in Welfare Department Office of East Java Province. This fact certainly affects the electability of dr. Samsul Azhar if it will still compete in this 2018 regional head election.

This unharmonious relationship triggered the sending of messages from party elites to candidate pairs not smooth. Political parties only provide temporary tickets for all logistical matters including funding support to be fully submitted to candidate pairs. Can you imagine how much money to be returned to the country?

The second pattern of communication is the implication of the first communication pattern in which the relationship between the elite and the candidate is full of obstacles. Horizontal patterns emphasize that party members and administrators can exchange information, either to fellow elites or to fellow members. Party decisions also consider the input of members who are often more emotionally charged than rationality. Described by Kusnadi as Chairman of East Java Regional Leadership Council:

"We've lobbied everything. So we've lobbied other parties. ... Being in a party is working between rationality and emotionality. Well if this is PDI Perjuangan, I say its ideological basis, then the emotionality is more in the decision making. Sometimes emotionality is much more pronounced than rationality. Because for us it's ok to lose, the most important thing is being solid. That's emotional. "

Feedback either in the form of suggestions or opinions can be direct but can also by using communication tools. He added:

"If that's the principle sir, we direct the communication. Face to face. Well, face to face it with DPP ...... or also directly to Mrs. Mega. But the face-to-face we build and which they ask for and that's what we do, it is not personal. It's institutional. So if those things are, if that's common with KSD (Chairman, Secretary, Treasurer). If the technical-course course, of course we use the existing communication tools. Call, WA, is that also yes SMS, yes all communication media".

Kusnadi statement is also strengthened by Jordan Bataragoa as Secretary of External Affairs DPD PDI Struggle East Java:

"At the provincial level, communication through WA is also very intense. We were also a lot of WA group diplomacy, both formal WA and non-formal WA. The non-formal WA is talking from A to Z, its participants. Even there is WA group, I think this is very interesting. Indeed, this WA group is quite informal but it is powerful."

Diagonal communication pattern is a pattern used when the communication process they continued gradually deteriorate. This happens because the members' aspirations are not responded well by the party leaders either at the level of the Branch (DPC), Regional (DPD) or Central (DPP). If the situation is protracted then the likelihood of exploding a conflict is surely great. This is very clearly illustrated when the vertical communication between DPC Kediri with candidate pairs carried not harmonious, then the candidate pair of Mayor (Samsul Azhar and Teguh Juniardi) directly complained to the upper level of the Regional Board of Management (DPD) of East Java. Here, they are also hampered. The choice is directly to the Central Executive Board (DPP) in Jakarta.

That fact confirms that manages the communication patterns in the organization of political parties in the era of disruptive been instrumental not easy (Priyowidodo, 2014). A rigid organizational structure approach should be adapted to a gentle organizational culture approach. Through such an approach, the communication pattern between the board and members or members with members is effective. Noteworthy, organizing in political 
parties is very fluid. Members, even administrators easily move the political parties if they do not feel like it. Indonesia has dozens of political parties with various ideologies.

In the 2019 legislative elections there are 20 political parties that compete, namely 16 national-level political parties include 1. National Mandate Party 2. Party Work 3. PDI Struggle 4. Democratic Party 5. Gerindra Party (Great Indonesia Movement) 6. Indonesian Movement Party 7. Golkar Party 8. Hanura Party (Conscience of the People) 9. Prosperous Justice Party 10. National Awakening Party 11. Democratic National Party 12. United Indonesian Party 13. United Development Party 14. Partai Solidaritas Indonesia (PSI). 15. Partai Bulan Bintang (PBB) and 16. Partai Keadilan dan Persatuan Indonesia (PKPI). While 4 local political parties namely the party of Aceh, party Sira, party Daerah Aceh and party Nanggroe Aceh. The number rises than the 2014 General Election which followed by only 12 political parties nationwide.

The phenomenon of activists moving between political parties in Indonesia is very common. That is why if the party-party relationships are not carefully considered, they can have a bad effect on voting in the next general election. Then the political party leaders have the obligation that remain adhered organizational discipline, relationships between friends also remains.

The map of political party deeds in Indonesia is divided into four main spectrums namely nationalist, Islam, socialism-democratic and Pancasila. A development that is not too far from what was formulated by Feith and Castles (1970) who divided the flow of Indonesian politics into five namely Radical-Nationalism, Javanese Traditionalism, Islam, Socialism-Democratic and Communism. Hidayat and Haryono (2004, in Nurjaman, 2009) divide into Traditionalist Islam, Modern Islam, Nationalist, Social Democrat, Marhaenism and Christian. While Mayruddin (2017) sees the ideological distance of each political party in the 2014 General Election into three namely the Left Party (Secular Nationalist: PDI Perjuangan, Gerindra, PKPI, Nasdem), Central Party (Catch-all party: Golkar, Democrat, Hanura) and the Right Party (Islam: PKS, PPP, PBB, PKB and PAN).

That is why decisions taken by political party officials must accommodate what interests the members. If not, they do not hesitate to get out of the membership of the political party. PDI Perjuangan as a big party in Indonesia, even in the 2014 general election is the winner of the election must carefully consider what the will of the people.

Various tools of communication in the era of Industrial Revolution 4.0 should be maximally used. Whatsapp, Facebook. Instagram, website, radio is a popular means of communication to absorb people's aspirations. In practice, social media has two benefits. First, political parties are helped to socialize the program to the public. And second, constituents or the public can communicate directly to party officials. Even very clearly recognized by Agus Sunoto, as Chairman of DPC PDI Perjuangan Kediri thus:

"Even now with the social media, we easily monitor the administrators in the branch (branch). We do enough coordination through WA (Whatsapp). Continue if there is an urgent organizational issue then we conduct a meeting at the office ".

The same thing is also recognized by the DPD of East Java and DPP PDI Perjuangan. Bambang DH as one of the Chairman of the DPP affirmed thus:

"Yes ....., the presence of social media is indeed very helpful organizational tasks. Just last week I coordinated with the troubled regional board in Sumatra. Today I am here. Next week I'm somewhere else. Coordination other than coming to the location of the scene, we also coordinate through social media. Even if someone claimed to be close to me, all proof. Junaidi, candidate for Deputy Mayor of Kediri, just met me twice, he said he had confessed that he was Bambang ". 
The pattern of communication that occurs in this political organization can be illustrated in the following visualizations:

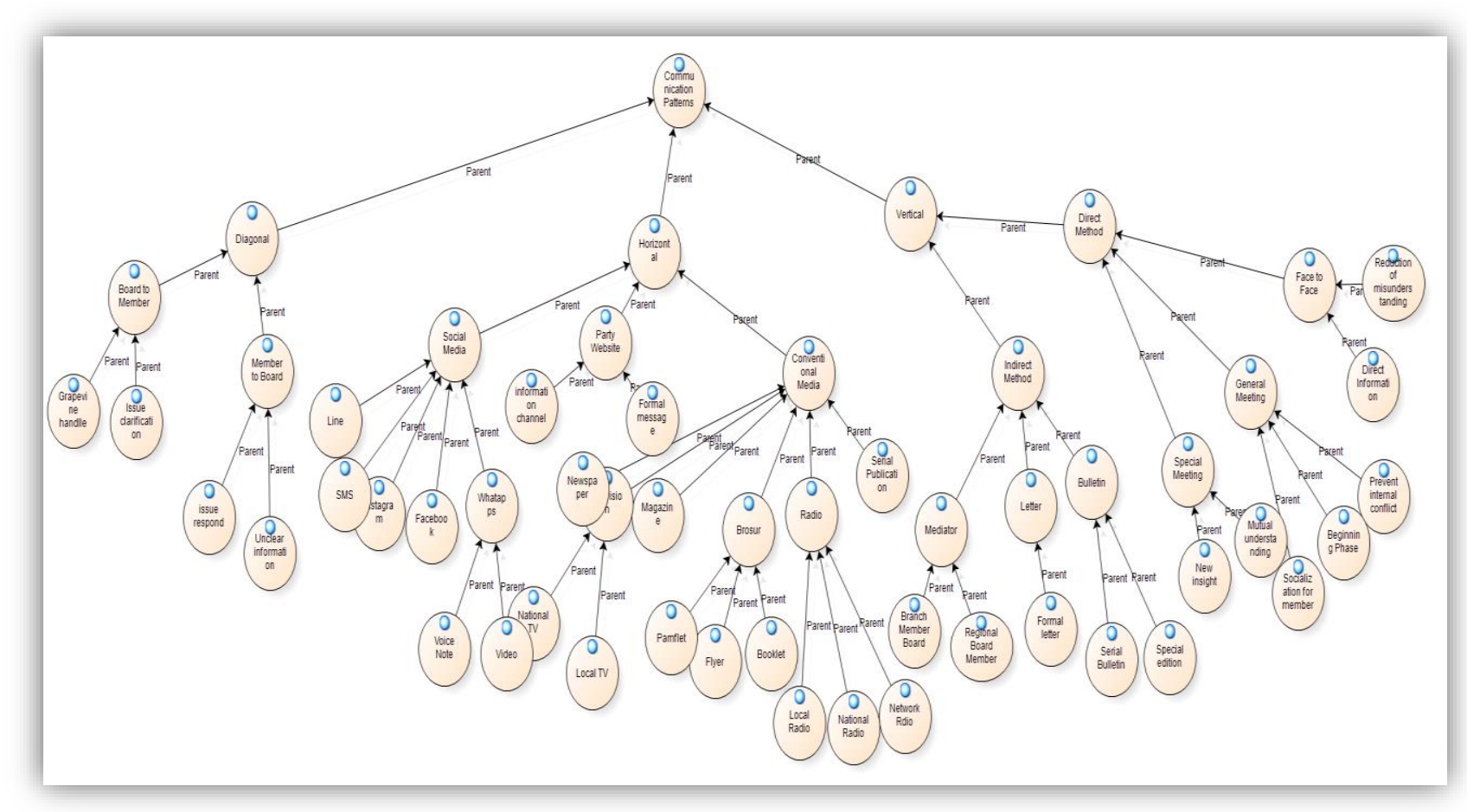

Figure 2

It is clear that three main patterns that dominate how decision making or determination of prospective head region carried out by the Indonesian Democratic Party of Struggle (PDI-Struggle).

Although the issuance of Letters of Recommendation is fully Megawati's absolute authority as Chairman of the PDIP, still aspiration of branch and the province remains listened. The goal, not to make public expectations and decisions taken by party officials has a very far gap. The case of the letter of recommendation from dr.Samsul Ashar with Teguh Juniadi is a clear example of how DPP also highly appreciates the members' struggle to be nominated by their own party. If only pay attention to the situation on the ground, it is better to participate in supporting incumbent candidates do not bother to collect votes. But because the PDI-P with the coalition felt able to nominate, it was agreed Samsul Ashar-Teguh Juniadi as a candidate.

Collaboration of vertical, horizontal and diagonal communication patterns became the strength of Samsul Ashar-Teguh Juniadi's partner in applying their political marketing strategy. Even by packing a political marketing strategy 'Hello Doctor' to be the right door to reach the target voters. The activity is also a means of proof that the volunteer's supporters of this pair remain solid even though DPC PDI Struggle organizational structure does not provide maximum support.

Another obstacle, social media accounts used by the couple Samsul Ashar-Teguh Juniadi repeatedly hacked by the opponent. Even more severe socio-economic capital in the form of health clinic facilities for treatment and hospitalization are revoked for operational licenses. Another internally built perception that the couple is not cooperative with the Board of Branch Management, because two invited meetings in the office of the DPC did not come. Practical, as if there is a systematic effort so that the candidate of this pair does not win the election competition Mayor 2018-2022. 


\section{Conclusion}

Based on the findings of the data and analysis that researchers do, communication patters carried out in a political party PDI-P Run to the coup three patterns of the vertical pattern (members of the board), horizontal pattern (members and board-board) as well as a diagonal pattern (members of the board members and administrators-members-managers).

The political marketing strategy used maximizes the use of social media to capture novice voters. Cultural approach through tagline "Halo pak dokter" as a means to communicate face to face with traditional audiences who are not yet familiar with social media.

\section{Acknowledgement}

This paper is a report of research results of PDUPT (Primary Research of Higher Education) funded by Kemristekdikti RI (The Ministry of Research, Technology, and Higher Education Republic of Indonesia) with the number of research contracts: 05/SP2H/LT/PDUPT/LPPM-UKP/III/2018. Thanks researchers to LPPM (The Centre of Research and Community Service) Petra Christian University, PDI-P: the Branch Executive Board of Kediri, the Regional Executive Board of East Java, the General Election Commission (KPU) of Kediri that has support field data.

\section{Reference}

Brodie, R.J. Ilic, A., Juric, B \& Hollebeek, L. (2013). Consumer engagement in virtual brand community : An exploratory analysis. Journal of Business Research, 66 (1), 105-114.

Cassata, M.B \& dan Asante, M. K. (1979). Mass Communication Principles and Practices.New York: Marcmillan

Culnan, M.J., \& Markus, M.L. (1987). Information Technologies dalam Jablin, F.M., Putnam, L.L., Roberts, K.H \& Porter, L.W (1987). Handbook of Organizational Communication, An Interdisciplinary Perspective. California: Sage Publication Inc.

Daft, R.L. \& Lewin, A.Y. (1993). Where are the theories for the new organization form? An editorial essay. Organization Science, 4 (4) p. i-vi

Daft, R.L., \& Lengel, R.H. (1986). Organizational information requirements, media richness and structural design. Management Science, 32, 554-571.

Dutton, J.E., Dukerich, J.M \& CV. Harquail (1994). Organization images and member identification. Administration Science Quartely, 39 239-263

Dutton, J.E., \& Dukerich, J.M (1991). Keeping an eye on the mirror: The Role of image and identityin organizational adaptation. Academy of Management Journal, 34, 517-554.

Edwardin, L.T.A.S (2006). Analisis Pengaruh Kompetensi Komunikasi, Kecerdasan Emosional, Dan Budaya Organisasi Terhadap Kinerja Karyawan (Studi Pada PT Pos Indonesia (Persero) Se Kota Semarang). Thesis, Semarang: PPS-Undip

Firmanzah.(2008). Marketing Politik : Antara Pemahaman Dan Realitas. Jakarta ～: Yayasan obor Indonesia.

Fuad Mas'ud (2004). Survai Diagnosis Organisasional. Konsep dan Aplikasi. Badan Penerbit UNDIP, Semarang

Goldman, SL, Nagel, RN, \& Preiss, K. (1995). Agile Competitors and Virtual Organizations: Strategies for Enriching the Customer. New York: Van Nostrand Reinhold,

Hammer, M., and J. Champy. (1993). Reengineering the Corporation. New York: HarperCollins Publishers.

Hiltz, S.R. (1994). The Virtual Classroom: Learning without Limits via Computer Networks. Norwood, NJ: Ablex

Hiltz, S.R., and B. Welman. (1997). Asynchronous Learning Networks as a Virtual Classroom. Communications of the ACM 40, no. 9: 44-4 
Jiyao, X \& Reynolds, J. (2010). Applying netnography to market research: the case of online forum. Journal of Targeting, Measurement and Analysis for Marketing, 18, 17-31

Kozinets, R.V. (2013). Netnography Doing Etnographic Research Online. Washington, DC: Sage Publication Ltd

Listianingtyas, B.A (2013). Persepsi Audiens Terhadap tingkatan Merek (Studi Netnography Pada Anggota Grup Harley-Davidson di Situs Jejaring Sosial Facebook Periode November 2010-Januari 2011, thesis, http:// e-journal.uajy.ac.id/780

Lock A. and Harris P. (1996) Political marketing - vive la difference. European Journal of Marketing, vol. 30, no. 10-11, pp. 21-31

McQuail, D. (2005). McQuail's mass communication theory edition: 5. London: SAGE.

Mochazondida, M. (2012). Netnographic Tourist Research: The Internet as a Virtual Fieldwork Site. Tourism Analysis, 17 (4), 553-555

Morreale, S.P., Spitzberg, B.H \& Barge, J.K (2006). Human Communication Motivation, Knowledge and Skill. Belmont, CA: Thomson Higher Education

Mowshowitz, A. (2002). Virtual Organization Toward a Theory of Societal Transformation Stimulated by Information Technology. Westport, CT : Quorum Books Greenwood Publishing Group, Inc.

Mowshowitz, A. (1994). Virtual Organization: A Vision of Management in the Information Age. The Information Society 10, no. 4: 267-288.

Newman, B. (1994). The Marketing of The President : Political Marketing as Campaign Strategy. Thousand Oaks, CA : Sage dalam Marshment, J.L (2009). Political Marketing : Principles and Applications. New York : Routledge

O'Shaughnessy, J. (2001). The marketing of political marketing. European Journal of Marketing, (35), 9-10. hlm. 1047-1067

Priyowidodo, G., Swestin, G., \& NurVidyarini, T. (2014). The Faces of Conflict in a Political Organization: The case of the Indonesia Democracy Party of Struggle (Partai Demokrsi Indonesia Perjuangan PDIP). Mediterranean Journal of Social Sciences, 5(19), 608. Retrieved from http://www.mcser.org/journal/index.php/mjss/article/view/4296

Safitri, Y. (2015). Menjadi Selegram Untuk menjadi Aktor: Strategi Pemerekan Personal Marlo Randy Ernesto. Jurnal Ilmiah Universitas Bakrie, 3 (3) http://jurnal.bakrie.ac.id/index.php/jurnal_ilmiah

Wiesenfeld, B.M., Raghuram, S. \& Garud, R. (1999). Communication Patterns as Determinants of Organizational Identification in a Virtual Organization. Organization Science, 10 (6), p.777-790

Wring (1997). Reconciling marketing with political science : theories of political marketing. Journal of Marketing Management, Vol. 13. pp.651-663 